\title{
PENGARUH GENDER, PENGHARGAAN FINANSIAL DAN PERTIMBANGAN PASAR KERJA TERHADAP MINAT MAHASISWA AKUNTANSI UNTUK BERKARIR MENJADI AKUNTAN PUBLIK DAN NON AKUNTAN PUBLIK
}

\author{
Astri Wulan Dary 1), Fitrawati Ilyas_2) \\ Fakultas Ekonomi dan Bisnis, Universitas Bengkulu ${ }^{1,2)}$ \\ Astriwulan12@gmail.com, fitrawatiilyas@yahoo.com
}

\begin{abstract}
The aim of this research is to examine and analyze the Influence of Gender, Financial Reward and Job Market considerations on intention of Accounting Students in Bengkulu City to have a career become Public Accountant and Non Public Accountant. This research is empirical research with quantitative approach which involves the use of statistical analysis. This research is using the primary data. Samples in this research consist of 160 accounting students of 1 public and 3 private Universities in Bengkulu City. The tool used in this research is logistic regression with SPSS software version 16. This study found that gender affect on the accounting students intention in Bengkulu City to have a career become public accountant and non public accountant, but financial reward and job market considerations this could not provide empirical evidence on the accounting students interest in bengkulu city to have a career become public accountant and non public accountant.
\end{abstract}

Keywords : Gender, Financial Reward and Job Market Considerations. The Interest to have a career become Public Accountant and Non Public Accountant

\section{PENDAHULUAN}

\section{Latar Belakang Permasalahan}

Salah satu aspek penting dalam kehidupan manusia dewasa yang sehat adalah karir. Ketepatan menentukan dan memilih karir menjadi titik penting dalam perjalanan hidup manusia, oleh karenanya karir seseorang berkontribusi besar bagi diri sendiri dan merupakan inti dari nilai dasar dan tujuan hidup seseorang. Pemilihan karir yang tepat sesuai minat dan bakat yang dimiliki seseorang merupakan tahap awal dalam pembentukan karir.

Pilihan karir bagi lulusan akuntansi tidak tertutup pada profesi akuntansi saja, banyak pilihan profesi yang dapat diselami oleh mereka tergantung faktor-faktor yang melatarbelakanginya. Misalkan seseorang yang mempunyai latar belakang pendidikan akuntansi atau S1 memiliki beberapa pilihan alternatif, antara lain yaitu melanjutkan untuk mengikuti pendidikan profesi akuntansi atau melanjutkan jenjang akademik S2 maupun langsung berkecimpung dalam dunia kerja. Dalam dunia kerja juga terdapat berbagai profesi yang dapat dijalankan oleh seorang sarjana akuntansi yaitu akuntan perusahaan, akuntan pemerintahan atau akuntan pendidik, akuntan publik. Jumlah akuntan publik di Indonesia saat ini secara kuantitas masih jauh dari kebutuhan jasa bagi dunia usaha. Berdasarkan data Institut Akuntan Publik Indonesia hanya sekitar 1.022 akuntan yang berpraktik sebagai akuntan publik pada tahun 2015, sedangkan sarjana yang memegang gelar akuntan melebihi jumlah 50.000 orang (Lukman, 2015). Dari jumlah akuntan publik di Indonesia pada umumnya didominasi oleh laki-laki yang berjumlah lebih kurang 791 orang, hanya sedikit perempuan yang memilih profesi menjadi akuntan publik sekitar lebih kurang 231 orang.

Sementara dalam memilih pekerjaan seseorang pasti mempertimbangkan gaji, upah maupun insentif dari hasil pekerjaannya atau bisa disebut penghargaan financial. Khususnya dalam profesi akuntan publik, karena kantor akuntan publik memiliki cara sendiri dalam 
memberikan gaji kepada auditornya. misalnya, jika proyek klien yang ditangani oleh kantor akuntan publik banyak, maka akuntan publik mendapatkan gaji yang besar. Namun sebaliknya, semakin sedikit proyek klien yang dikerjakan oleh akuntan publik maka akan semakin kecil pula gaji yang akan didapatkan.

Pertimbangan pasar kerja menjadi salah satu alasan yang berpengaruh terhadap minat seseorang dalam berkarir. Profesi yang memiliki pasar kerja yang luas akan lebih diminati dari pada profesi dengan pasar kerja yang kecil (Zaid, 2015). penelitan Lukman (2015) menunjukan bahwa nilai-nilai intrinsik, persepsi mahasiswa dan pengaruh orang tua terhadap kecenderungan mahasiswa untuk bekerja sebagai akuntan publik itu berpengaruh signifikan, sementara gender, pertimbangan pasar kerja tidak memiliki pengaruh yang signifikan. Sedangkan hasil penelitian Zaid, (2015) ini menunjukan bahwa tidak terdapat pengaruh gender terhadap minat mahasiswa akuntansi untuk berkarir menjadi akuntan publik. Namun untuk penghargaan finansial dan pertimbangan pasar kerja berpengaruh signifikan terhadap minat mahasiswa akuntansi untuk berkarir menjadi Akuntan Publik. Sedangkan, gender, penghargaan finansial, dan pertimbangan pasar kerja secara bersama-sama berpengaruh terhadap minat Mahasiswa Akuntansi untuk berkarir menjadi Akuntan Publik.

\section{Landasan Teori dan Pengembangan Hipotesis}

The Theory of Reasoned Action (TRA)

Menurut Law (2010) The Theory of reasoned action (TRA) model menjelaskan suatu asal-usul di bidang psikologi sosial. Model ini dikembangkan oleh Fishbein dan Ajezen dalam Law (2010) yang mengatakan bahwa perilaku seseorang ditentukan oleh niat. Niat itu sendiri ditentukan oleh sikap dan norma-norma subjektif mereka terhadap perilaku. Attitude (Law, 2010) dijelaskan sebagai sikap terhadap perilaku yang dituangkan dalam perasaan positif atau negatif secara individu dalam bertindak. Hal ini ditentukan melalui penilaian dari keyakinan seseorang mengenai konsekuensi yang timbul dari perilaku dan evaluasi keinginan konsekuensi. Secara formal, sikap keseluruhan dapat dinilai sebagai akumulasi dari penilian keinginan konsekuensi tertentu dari individu untuk semua konsekuensi yang diharapkan dari perilaku (Law, 2010). Sedangkan Subjective norms adalah didefinisikan sebagai persepsi individu dari orang-orang penting untuk individu berpikir untuk melakukan pemikiran mereka. Kontribusi pendapat setiap rujukan yang diberikan dipertimbangkan dengan motivasi bahwa seseorang harus memenuhi keinginan rujukan itu. Oleh karena itu, secara keseluruhan norma subjektif dapat dinyatakan sebagai jumlah atau akumulasi dari penilaian motivasi persepsi tertentu bagi individu untuk semua acuan yang relevan (Law, 2010).

Hubungan Attitudes dan Subjects Norms dalam keinginan berprilaku seseorang dapat digambarkan seperti dibawah ini.

\section{Gambar 2.1 : The Theory of Reasoned Action Model}

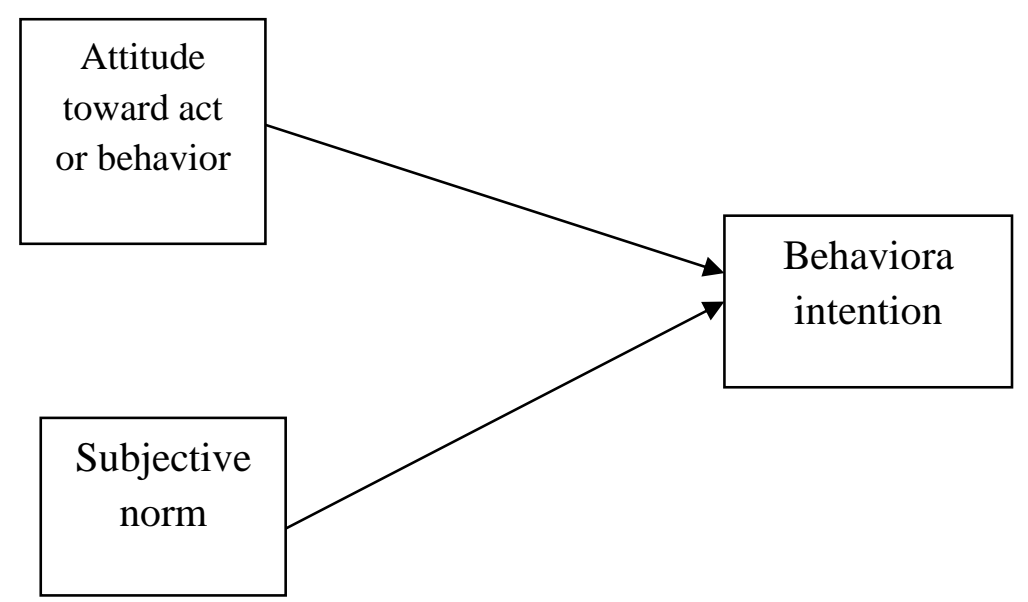


Lebih lanjut Law (2010) menjelaskan bahwa TRA digunakan sebagai model yang berhubungan antara attitudes dan pemilihan karir seseorang. Model ini memberikan suatu social psychological framework yang berguna menjelaskan jenis-jenis perilaku (Ajzen and Fishbein, 1980; Sheppard et al., 1988; Sable et al., 2006 dalam Law 2010), dan telah direkomendasikan sebagai suatu yang kerangka yang berguna untuk eksaminasi variabelvariabel yang mempengaruhi pemilihan karir (Cohen and Hanno, 1993 dalam Law 2010). TRA yang mencirikan perilaku manusia sebagai sesuatu yang "disengaja" (intentional) dan rasional (rational). Dengan demikian, TRA dapat memprediksi bahwa niat siswa untuk mengejar karir menjadi akuntan publik maupun non akuntan publik harus sangat terkait dengan attitude dan subjectives norms terhadap karir tersebut. Dimana persepsi mahasiswa akan mempengaruhi minat berkarir menjadi akuntan publik dan non akuntan publik yang di pilih, dimana kelompok perilaku terdapat penghargaan finansial dan kelompok subjectives norms terdapat pertimbangan pasar kerja. Sedangkan gender memiliki keterkaitan dengan attitude dan subjectives norms.

\section{Pengembangan Hipotesis}

\section{Gender}

Women's Studies Encyclopedia dalam Mufidah (2003:3) menjelaskan gender sebagai suatu konsep kultural yang berupaya membuat perbedaan dalam hal peran, perilaku, mentalitas, dan karakteristik emosional antara laki-laki dan perempuan yang berkembang dalam masyarakat. Peran gender sangat penting dampaknya dalam tiap aktivitas yang dilakukan oleh manusia, dan dalam hal karir menjadi akuntan publik ini kadang orang berpandangan bahwa mungkin perempuan tidak telalu bagus jika menjadi akuntan publik dilihat dari jenis pekerjaan yang dapat menyita waktu perempuan mengurus keluarganya (Ernawati: 2004). Hal ini berbeda dengan yang diungkapkan oleh Law (2010) yang meneliti di Hong Kong menyebutkan bahwa kebanyakan wanita yang memasuki profesi akuntan publik. Dari uraian diatas, dirumuskan hipotesis sebagai berikut:

$\mathrm{H}_{1}$ : Gender mempunyai pengaruh terhadap Minat Mahasiswa Akuntansi untuk Berkarir Menjadi Akuntan Publik dan non Akuntan Publik.

\section{Penghargan finansial}

Penghargaan Finansial merupakan pertimbangan pertama seorang mahasiswa dalam pemilihan karir yang akan dipilih sebagai akuntan publik maupun non akuntan publik. Penghargaan finansial yang diperoleh sebagai kontraprestasi dari pekerjaan telah diyakini secara mendasar bagi sebagian besar perusahaan sebagai daya tarik utama untuk memberikan kepuasan kepada karyawannya (Aprilyan: 2011). Menurut penelitian Zaid (2015) penghargaan finansial berpengaruh signifikan terhadap minat mahasiswa menjadi akuntan publik, hal ini berarti apabila penghargaan finansial semakin baik maka mengakibatkan minat mahasiswa menjadi akuntan publik semakin besar. Sedangkan menurut Suyono (2014) menunjukan bahwa variabel penghargaan finansial secara parsial berpengaruh signifikan terhadap pemilihan karir sebagai akuntan publik. Semakin tinggi penghasilan yang ditawarkan, semakin besar pula minat mahasiswa untuk memilih profesi tersebut. Akuntan merupakan salah satu profesi dengan penghasilan yang relative tinggi dibandingkan dengan profesi lainnya. untuk itu peneliti berpendapat ada pengaruh antara penghasilan dengan minat mahasiswa akuntansi untuk berkarir sebgai akuntan publik.

$\mathrm{H}_{2}$ : Penghargaan Finasial mempunyai Pengaruh terhadap minat mahasiswa menjadi Akuntan Publik dan non Akuntan Publik. 


\section{Pertimbangan pasar kerja}

Pertimbangan pasar kerja berhubungan erat dengan pekerjaan yang dapat diakses di masa yang akan datang. Pekerjaan yang memiliki pasar kerja yang lebih luas akan lebih diminati dari pada pekerjaan yang pasar kerjanya kecil. Menurut Lukman (2015) Pertimbangan masa depan suatu karir yang mudah diakses atau tersedia yang mana akan ditekuni dan dijalankan pada masa depan merupakan harapan yang dipengaruhi oleh ketersediaan karir dipasar tenaga kerja. Begitu pula hasil penelitian Aprilyan (2011) yang menemukan bahwa faktor pertimbangan pasar kerja merupakan faktor yang mempengaruhi mahasiswa dalam memilih profesi sebagai akuntan publik. Sedangkan menurut Suyono (2014) menunjukan bahwa variabel pertimbangan pasar kerja secara parsial berpengaruh signifikan terhadap pemilihan karir sebagai akuntan publik dan non akuntan publik. Dari uraian diatas, dirumuskan hipotesis sebagai berikut.

$\mathrm{H}_{3}$ : Pertimbangan pasar kerja mempunyai pengaruh terhadap minat mahasiswa akuntansi untuk berkarir menjadi akuntan publik dan non Akuntan Publik.

\section{Metode Penelitian}

Penelitian ini menggunakan penelitian kuantiatif dan sumber data yang digunakan dalam penelitian ini diperoleh dari hasil penyebaran kuesioner. Populasi dalam penelitian ini adalah mahasiswa akuntansi dan metode pengambilan sampel menggunakan random sampling dan sampel dalam penelitian ini sebanyak 160 responden. Metode analisis data yang digunakan adalah regresi logistik. Taraf signifikansi yang digunakan adalah 5\%.

\section{HASIL DAN PEMBAHASAN}

\section{Data Deskripsi}

Penelitian ini menggunakan data primer yang diperoleh dengan cara survey dan menyebarkan kuesioner kepada responden. Kuesioner tersebut dibagikan kepada sampel yang memenuhi criteria sampel. Populasi dalam penelitian ini adalah mahasiswa se-Kota Bengkulu yang terdiri dari Univeristas Bengkulu, Universitas Muhammadiyah Bengkulu, Universitas Dehasen, dan Universitas Hazairin. Dimana mahasiswa yang menjadi criteria yaitu mahasiswa sangkatan tahun 2012.

Tabel 4.1

Rincian Tingkat Pengembalian Kuesioner

\begin{tabular}{l|c|c}
\hline \multicolumn{1}{c|}{ Rincian } & Jumlah (Eks) & Persentase (\%) \\
\hline Kuesioner yang disebar & 180 & 100 \\
\hline Kuesioner yang dikembali & 165 & 87,5 \\
\hline Kuesioner yang tidak kembali & 15 & 12,5 \\
\hline Keusioner yang tidak dapat diolah & 5 & 4,16 \\
\hline $\begin{array}{l}\text { Kuesioner yang dapat digunakan } \\
\text { (dianalisis) }\end{array}$ & 160 & 100 \\
\hline
\end{tabular}

Sumber : data Primer diolah, 2016

Berdasarkan table 4.1 di atas, Jumlah kuesioner yang disebarkan dalam penelitian adalah 180 eksemplar. Dari jumlah yang disebarkan kepada responden, ada 165 kuesioner yang kembali, sebanyak 15 kuesioner tidak kembali dan 5 kuesioner tidak dapat digunakan. 
Adapun alasan tidak dapat digunakan karena responden mengisi jawaban tidak lengkap dan tidak memenuhi kriteria sampel yang ditetapkan.

\section{Statistik Deskriptif}

Statistik deskriptif memberikan gambaran atau deskripsi suatu data yang dilihat dari nilai rata-rata (mean), standar deviasi, minimum, dan maksimum. Tabel 4.3 menyajikan hasil statistik deskriptif untuk variabel bebas dan variabel kontrol pada penelitian ini adalah sebagai beriku:

Tabel 4.3

Statistik Deskriptif Variabel Penelitian

\begin{tabular}{|c|c|c|c|c|c|c|}
\hline Variabel & $\mathrm{n}$ & $\begin{array}{l}\text { Kisaran } \\
\text { Teoritis }\end{array}$ & $\begin{array}{c}\text { Kisaran } \\
\text { Aktual }\end{array}$ & $\begin{array}{c}\text { Mean } \\
\text { Teoritis }\end{array}$ & $\begin{array}{l}\text { Mean } \\
\text { Aktual }\end{array}$ & Std. Deviasi \\
\hline GENDER & & & & & & \\
\hline Minat Akuntan Publik & 121 & $0-1$ & $0-1$ & 0,5 & 0,43 & 0,497 \\
\hline Minat Non Akuntan Publik & 39 & $0-1$ & $0-1$ & 0,5 & 0,74 & 0,442 \\
\hline Total & 160 & $0-1$ & 0,000 & 0,5 & 0,51 & 0,502 \\
\hline $\begin{array}{l}\text { PENGHARGAAN } \\
\text { FINANSIAL }\end{array}$ & \multirow[b]{2}{*}{121} & \multirow[b]{2}{*}{$5-25$} & \multirow[b]{2}{*}{$12-25$} & \multirow[b]{2}{*}{15} & \multirow[b]{2}{*}{19,84} & \multirow[b]{2}{*}{2,944} \\
\hline Minat Akuntan Publik & & & & & & \\
\hline Minat Non Akuntan Publik & 39 & $5-25$ & $14-24$ & 15 & 19,00 & 2,328 \\
\hline Total & 160 & $5-25$ & $12-25$ & 15 & 19,64 & 2,820 \\
\hline $\begin{array}{l}\text { PERTIMBANGAN PASAR } \\
\text { KERJA }\end{array}$ & \multirow{2}{*}{121} & \multirow[b]{2}{*}{$5-25$} & \multirow{2}{*}{$10-25$} & \multirow{2}{*}{15} & \multirow{2}{*}{19,71} & \multirow{2}{*}{2,853} \\
\hline Minat Akuntan Publik & & & & & & \\
\hline Minat Non Akuntan Publik & & & & & & \\
\hline \multirow[t]{2}{*}{$\begin{array}{r}\text { Total } \\
\end{array}$} & 39 & $5-25$ & $15-25$ & 15 & 20,46 & 2,624 \\
\hline & 160 & $5-25$ & $10-25$ & 15 & 19,89 & 2,810 \\
\hline
\end{tabular}

Sumber: Data primer diolah, 2016

Berdasarkan tabel 4.3 di atas menunjukan deskriptif semua variabel dari 160 responden yang menjadi sampel penelitian. Variabel gender, penghargaan finansial dan pertimbangan pasar kerja diklasifikasikan menjadi dua yaitu minat mahasiswa akuntansi sekota Bengkulu dalam memlilih karir menjadi akuntan publik ada sebanyak 121 orang dan minat non akuntan publik sebanyak 39 orang. Pada variabel gender klasifikasi minat akuntan publik mempunyai nilai minimum 0 dan nilai maksimum 1 karena variabel gender adalah variabel dummy, nilai 0 menandakan bahwa laki-laki sedangkan nilai 1 menandakan perempuan. Minat menjadi akuntan publik pada mahasiswa laki-laki berjumlah 69 orang dan perempuan berjumlah 52 orang dengan total 121 orang yang berminat menjadi akuntan publik, yang berarti minat menjadi akuntan publik didominasi oleh laki-laki. Variabel gender pada klasifikasi minat menjadi akuntan publik menunjukan rata-rata aktual adalah 0,43 yang lebih kecil dari nilai teoritisnya 0,5 . Standar deviasi pada variabel gender adalah 0,497 yang menunujkkan bahwa jawaban dari responden bervariasi.

Variabel gender Pada minat non akuntan publik mempunyai nilai minimum 0 dan nilai maksimum 1 karena variabel gender adalah variabel dummy, nilai 0 menandakan bahwa lakilaki sedangkan nilai 1 menandakan perempuan. Minat non akuntan publik pada mahasiswa laki-laki berjumlah 10 orang dan perempuan berjumlah 29 orang, yang berarti minat non akuntan publik didominasi oleh perempuan. Variabel gender pada klasifikasi minat menjadi 
akuntan publik menunjukan rata-rata aktual adalah 0,74 yang lebih kecil dari nilai teoritisnya 0,5. Standar deviasi pada variabel gender adalah 0,442 yang menunujkkan bahwa jawaban dari responden bervariasi.

Variabel gender mempunyai nilai minimum 0 dan nilai maksimum 1 karena variabel gender adalah variabel dummy, nilai 0 menandakan bahwa laki-laki sedangkan nilai 1 menandakan perempuan. Variabel gender pada klasifikasi minat menjadi akuntan publik maupun non akuntan publik menunjukan rata-rata aktual adalah 0,51 yang lebih kecil dari nilai teoritisnya 0,5 . Standar deviasi pada variabel gender adalah 0,502 yang menunujkkan bahwa jawaban dari responden bervariasi.

Penghargaan finansial pada klasifikasi minat mahasiswa menjadi akuntan publik menunujukan rata-rata aktual sebesar 19,84 yang lebih besar dari nilai teoritis yaitu 15 . Standar deviasi pada variabel penghargaan finansial adalah 2,944 yang menunujkkan bahwa jawaban dari responden bervariasi. Penghargaan finansial pada klasifikasi minat mahasiswa non akuntan publik menunujukan rata-rata aktual sebesar 19,00 yang lebih besar dari nilai teoritis yaitu 15. Standar deviasi pada variabel penghargaan finansial adalah 2,328 yang menunujkkan bahwa jawaban dari responden bervariasi.

Penghargaan finansial pada klasifikasi minat mahasiswa menjadi akuntan publik maupun non akuntan publik menunujukan rata-rata aktual sebesar 19,64 yang lebih besar dari nilai teoritis yaitu 15. Standar deviasi pada variabel penghargaan finansial adalah 2,820 yang menunujkkan bahwa jawaban dari responden bervariasi. Pertimbangan Pasar kerja pada klasifikasikan minat mahasiswa menjadi akuntan publik menujukkan rata-rata actual sebesar 19,71 yang lebih besar dari nilai teoritisnya yaitu 15. Standar deviasi pertimbangan pasar kerja adalah 2,853 yang menunjukan bahwa jawaban responden bervariasi.

Pertimbangan Pasar kerja pada klasifikasikan minat mahasiswa non akuntan publik menujukkan rata-rata aktual sebesar 20,46 yang lebih besar dari nilai teoritisnya yaitu 15 . Standar deviasi pertimbangan pasar kerja adalah 2,624 yang menunjukan bahwa jawaban responden bervariasi. Pertimbangan Pasar kerja pada klasifikasi minat mahasiswa menjadi akuntan publik maupun non akuntan publik menunujukan rata-rata aktual sebesar 19,89 yang lebih besar dari nilai teoritisnya yaitu 15. Standar deviasi pertimbangan pasar kerja adalah 2,624 yang menunjukan bahwa jawaban responden bervariasi.

\section{Pengujian Hipotesis}

Penelitian ini bertujuan untuk menjelaskan faktor-faktor yang mempengaruhi minat mahasiswa akuntansi berkarir menjadi akuntan publik dan non akuntan publik. Hipotesis tersebut dalam penelitian ini diuji dengan menggunakan regresi logistik. Untuk menguji kelayakan model dalam penelitian ini dengan melihat perbandingan nilai -2 log likehood awal (hasil block number 0) dengan nilai -2 log likehood (hasil block number 1).

\section{Tabel 4.6}

Likelihood Overall Fit Block

\begin{tabular}{|c|c|c|}
\hline \multicolumn{2}{|c|}{ Iteration } & -2 log likehood \\
\hline Step 0 & 1 & 177,717 \\
\hline Step 1 & 1 & 163,929 \\
\hline 2 & & 161,405 \\
\hline 3 & & 161,348 \\
\hline 4 & & 161,348 \\
\hline 5 & & 161,348 \\
\hline
\end{tabular}

Sumber: Data primer yang diolah, 2016 
Pengujian pada block number 0 (pengujian dengan memasukkan semua prediktor) memperoleh nilai -2 log likehood awal 177,717. Nilai tersebut menunjukkan bahwa tidak mengalami penurunan (tetap) yang berarti model belum dapat menjelaskan hubungan variabel bebas dengan variabel terikatnya. Sedangkan pada block number 1 diperoleh nilai $-2 \log$ likehood sebesar 161,348. Hal ini menunjukkan bahwa adanya penurunan nilai -2 log likehood, sehingga memungkinkan adanya hubungan antara variabel independen dengan variabel dependennya.

Table 4.7

Model Summary

\begin{tabular}{l|c|r|r}
\hline Step & $\begin{array}{c}-2 \text { Log } \\
\text { likelihood }\end{array}$ & $\begin{array}{c}\text { Cox \& Snell R } \\
\text { Square }\end{array}$ & $\begin{array}{c}\text { Nagelkerke R } \\
\text { Square }\end{array}$ \\
\hline 1 & $161.348^{\mathrm{a}}$ & .097 & .145 \\
\hline
\end{tabular}

a. Estimation terminated at iteration number 5 because parameter estimates changed by less than ,001.

Nilai hasil Nagelkerke $R$ Square dapat dijelaskan oleh variabel independen sebesar $14,5 \%$, sementara sisanya $85,5 \%$ dapat dijelaskan oleh variabel lain yang tidak digunakan pada penelitian ini. Setelah mendapat model regresi logistik yang fit yang tidak memerlukan modifikasi model, maka pengujian hipotesis dapat dilakukan. Untuk menerimaan atau penolakan hipotesis didasarkan pada tingkat signifikansi $(\alpha) 0,05(5 \%)$ dengan kriteria apabila nilai signifikan (Sig.) $>$ tingkat signifikansi $(\alpha)$, maka $\mathrm{H} 0$ diterima atau Ha ditolak. Sebaliknya, apabila nilai signifikan $($ Sig. $)<$ tingkat signifikansi $(\alpha)$, maka H0 ditolak atau Ha diterima.

Tabel 4.7

Hasil Regresi Logistik

\begin{tabular}{c|c|c|c}
\hline Variabel & Koefisien & Sig. & Ket. \\
\hline Gender (X1) & $-1,380$ & 0,001 & Diterima \\
\hline Penghargaan Finansial (X2) & 0,079 & 0,249 & Ditolak \\
\hline Pertimbangan Pasar Kerja X(3) & $-0,111$ & 0,134 & Ditolak \\
\hline Constanta & 2,643 & 0,227 & \\
\hline
\end{tabular}

Sumber: Data primer yang diolah, 2016

Bentuk persamaan regresi logistik dapat ditulis sebagai berikut:

$$
\log Y=2,643+(-1,380) X 1+0,079 X 2+(-0,111) X 3+e
$$

\section{Hasil Pengujian Hipotesis}

\section{Gender (X1)}

Hasil pengujian hipotesis menunjukan bahwa gender memiliki nilai signifikansi sebesar 0,001. Nilai sig. 0,001 <0,05 menunjukan bahwa variabel gender terbukti memiliki pengaruh terhadap minat mahasiswa akuntansi berkarir menjadi akuntan publik dan non akuntan publik sehingga hipotesis diterima. Artinya Hasil penelitian ini konsisten dengan penelitian yang dilakukan oleh Ernawati (2004) yang menunjukan bahwa gender memiliki pengaruh signifikan terhadap pemilihan karir menjadi akuntan publik dan Peran gender sangat penting dampaknya dalam tiap aktivitas yang dilakukan oleh manusia. Hal ini berbeda dengan yang diungkapkan oleh Law (2010) dalam The Theory of reasoned action yang meneliti di Hong Kong menyebutkan bahwa kebanyakan wanita yang memasuki profesi akuntan publik. 
Jadi, perbedaan gender pada saat ini menjadi hambatan bagi seseorang dalam menemukan profesi dan karir yang mereka geluti. Karena telah dibuktikan pada hasil statistik deskriptif yang menunjukkan bahwa kebanyakan laki-laki yang memilih profesi akuntan publik. Sedangkan perempuan memilih profesi non akuntan publik. Karena, kemungkinan perempuan tidak telalu bagus jika menjadi akuntan publik dilihat dari jenis pekerjaan yang dapat menyita waktu perempuan mengurus keluarganya.

\section{Penghargaan Finansial}

Hasil pengujian hipotesis menunjukan bahwa penghargaan finasial memiliki nilai signifikansi sebesar 0,249. Nilai sig. 0,249>0,05 menunjukan bahwa variabel penghargaan finansial terbukti tidak memiliki pengaruh terhadap minat mahasiswa akuntansi berkarir menjadi akuntan publik dan non akuntan publik sehingga hipotesis ditolak. Artinya, yang menyebabkan hasil ini tidak signifikan terhadap minat mahasiswa akuntansi berkarir menjadi akuntan publik dan non akuntan publik karena ada jawaban beberapa responden yang tidak setuju dengan pernyataan mengenai gaji awal yang tinggi dan kemungkinan ini lah yang menyebabkan mahasiswa ingin mendapatkan variasi pengalaman kerja terlebih dahulu. Hasil penelitian ini konsisten dengan penelitian yang dilakukan oleh Chan (2012) yang menunjukkan bahwa penghargaan finansial tidak berpengaruh terhadap minat mahasiswa akuntansi Sekota Bengkulu menjadi akuntan publik dan non akuntan publik. Namun, tidak konsisten dengan penelitian yang dilakukan Law (2010) menunjukkan bahwa hasil pengaruh yang negatif dan tidak signifikan terhadap mahasiswa yang berniat menjalani karier pada CPA dan profesi akuntansi lainnya.

\section{Pertimbangan Pasar Kerja}

Hasil pengujian hipotesis menunjukan bahwa pertimbangan pasar kerja memiliki nilai signifikansi sebesar 0,134. Nilai sig. 0,134 >0,05 menunjukan bahwa variabel pertimbangan pasar kerja terbukti tidak memiliki pengaruh terhadap minat mahasiswa akuntansi berkarir menjadi akuntan publik dan non akuntan publik sehingga hipotesis ditolak. Artinya, yang menyebabkan hasil tidak signifikan adalah adanya jawaban responden yang tidak setuju dengan pernyataan pada setiap item pertanyaan yakni 12 responden yang tidak setuju dengan pernyataan lapangan kerja yang mudah diakses dari 160 responden, 14 responden yang tidak setuju dengan pernyataan keamanan kerjanya lebih terjamin tidak mudah di PHK, 12 responden yang tidak setuju dengan pernyataan karir tesebut dapat memperluas akses dan pengetahuan isu-isu dunia bisnis dan akuntansi terkini dan 13 responden yang tidak setuju bahwa pekerjaan ini memebrikan pilihan jenis pekerjaan yang luas. Hal ini mengindikasikan bahwa kurangnya informasi terkait pertimbangan pasar kerja akuntan publik dan non akuntan publik dan pekerjaan tersebut dianggap tidak luas. Hasil penelitian yang dilakukan oleh Chan (2012), Sartika (2014), Lukman (2015) yang menunjukkan bahwa pertimbangan pasar kerja tidak berpengaruh terhadap minat mahasiswa akuntansi menjadi akuntan publik dan non akuntan publik.

\section{PENUTUP}

Berdasarkan hasil penelitian dan pembahasan yang telah dikemukakan pada bab sebelumnya, dapat ditarik kesimpulan sebagai berikut :

1. Laki-laki cenderung memilih akuntan publik dan perempuan memilih non akuntan publik, maka gender memiliki pengaruh terhadap minat mahasiswa akuntansi berkarir menjadi akuntan publik dan non akuntan publik di Perguruan Tinggi Negeri dan Perguruan Tinggi Swasta. 
2. Penghargaan Finansial tidak memiliki pengaruh terhadap minat mahasiswa akuntansi berkarir menjadi akuntan publik dan non akuntan publik di Perguruan Tinggi Negeri dan Perguruan Tinggi Swasta.

3. Pertimbangan Pasar Kerja tidak memiliki pengaruh terhadap minat mahasiswa akuntansi berkarir menjadi akuntan publik dan non akuntan publik di Perguruan Tinggi Negeri dan Perguruan Tinggi Swasta.

\section{Keterbatasan dan Saran}

a. Keterbatasan

1. Karena di PTS dan PTN mahasiswa dikumpulkan hanaya yang bisa dihubungi oleh peneliti dan bagian akademik, kebanyakan dari responden adalah mahasiswa yang telah lulus dari mata kuliah tersebut, sehingga pengetahuan hal yang diuji sudah terlupakan.

2. Jumlah sampel yang tidak sama, sehingga menyebabkan variance data cenderung tidak homogen. Karena data cenderung tidak homogen maka data terdistribusi tidak normal.

b. Saran

Adapun saran yang diberikan untuk penelitian yang akan datang sebagai berikut:

1. Untuk penelitian selanjutnya disarankan untuk mengembangkan penelitian ini dengan juga meneliti faktor-faktor lain yang berpengaruh terhadap pemilihan karir sebagai akuntan publik yang tidak diteliti oleh peneliti. Di samping itu juga menambah metode lain di luar kuesioner untuk mengatasi kelemahan-kelemahan yang mungkin terdapat pada metode kuesioner.

2. Penelitian selanjutnya dapat menggunakan sampel di seluruh perguruan tinggi di Provinsi Bengkulu sehingga dapat dibandingkan tingkat perbedaan pemahaman terhadap suatu konsep akuntansi antara seluruh perguruan tinggi di Provinsi Bengkulu.

3. Penelitian selanjutnya diharapkan dapat membuat peneliti ini tidak hanya penelitian kuantitatif melainkan gabungan dengan penelitian kualitatif.

\section{DAFTAR PUSTAKA}

Aprilyan, Lara Absara. 2011. Faktor-faktor yang mempengaruhi mahasiswa akuntansi dalam pemilihan karir menjadi Akuntan Publik. Jurnal Ilmiah Mahasiswa Akuntansi.

Chan, Andi Setiawan. 2012. Analisis faktor-faktor yang mempengaruhi pemilihan karir menjadi Akuntan publik oleh mahasiswa Jurusan Akuntansi. Jurnal Ilmiah Mahasiswa Akuntansi. (1.1). hal. 53-58

Ernawati dan Edi Wibowo. 2004. Pengaruh Gender Terhadap Keinginan Mahasiswa Akuntansi dalam Memilih Profesi Akuntan Publik dan Non Akuntan Publik. Jurnal Ekonomi dan Kewirausahaan. 4 (I).Hlm. 56-65.

Law, Philip K. 2010. A theory of reasoned action model of accounting students' career choice in public accounting practices in the post-Enron. Journal of Applied Accounting Research.(11.1). hal. 58-73

Lukman, Hendro. 2015. Pengaruh Nilai Intrisik, Gender, Parental influence, persepsi mahasiswa dan pertimbangan pasar kerja dengan pendekatan Theory Of Reasoned Action Model terhadap pemilihan karir sebagai akuntan publik bagi Mahasiswa 
Pengaruh Gender, Penghargaan Finansial

Astri Wulan Dary dan Fitrawati Ilyas

Perguruan Tinggi Swasta di Jakarta. Proceding Simposium Nasional Akuntansi 18 Medan.

Mufidah. 2003. Paradigma Gender. Malang: Bayu media Publishing

Sartika, Meli. 2014. Faktor-Faktor yang Mempengaruhi Minat Pemilihan Karir Sebagai Akuntan Publik dan Non Akuntan Publik. Skripsi Bengkulu: Universitas Bengkulu

Zaid, Muhammad Ikhwan. 2015. Pengaruh Gender, Penghargaan Finansial, dan Pertimbangan Pasar Kerja terhadap Minat Mahasiswa Akuntansi untuk Berkarir Menjadi Akuntan Publik. Universitas Negeri Yogyakarta. Jurnal Ilmiah Mahasiswa Akuntansi 